\title{
AN EMPIRICAL REVIEW ON THE GRADUATE ATTRIBUTES AND READINESS FOR EMPLOYABILITY AMONG THE ENGINEERING GRADUATES IN THE HIGHER EDUCATION INSTITUTIONS (HEIs)
}

\author{
Masoud Rashid Al Hinai \\ PhD Research Fellow \\ Faculty of Business and Accountancy \\ University of Selangor \\ 40000 Shah Alam, Selangor Darul Ehsan, Malaysia \\ E-mail: alhinai6602@gmail.com \\ Dr. Abul Bashar Bhuiyan \\ Associate Professor \\ Faculty of Business and Accountancy \\ University of Selangor \\ 40000 Shah Alam, Selangor Darul Ehsan, Malaysia \\ E-mail: bashariuk@gmail.com \\ Dr. Nor Azilah Husin \\ Associate Professor \& Deputy Dean \\ Faculty of Business and Accountancy \\ University of Selangor \\ 40000 Shah Alam, Selangor Darul Ehsan, Malaysia \\ E-mail: nor_azilah@unisel.edu.my
}

\begin{abstract}
The graduates' readiness for employability has become a major issue for HEIs in the world due to growing concern from governments and industries on the quality of the graduates. As thus, this paper intends to determine the most required skills for Engineering graduate's readiness for employability. Therefore, the main objective of the current study is to determine the skills required for Graduates' Readiness for Employability for Engineering graduates. Specifically, this study intends to review the most current literature to specify the most required skills for the readiness of Engineering Graduates for Employability in the Higher Education Institutes (HEIs) in the world. The study reviews the current literature on graduates' readiness for employability especially for engineering graduates as the main source of information. The study is designed to analyze and determine the engineering graduates' readiness for employability required skills. The literature utilized for this study covers the latest literature (from 2014 to 2019) extracted from Google Scholar, ProQuest, and Scopus. The three main keywords used were 'higher education', 'employability skills 'or 'readiness for employability skills, and 'skills gap in the world. The study determines the engineering graduates' readiness for employability required
\end{abstract}


skills for the HEIs in the world. It analyses the most influential required skills for the graduate readiness for employability that will be considered as an empirical study on the graduates of the engineering colleges in the world. The study conceptualizes graduate readiness for employability requirements from the latest literature and papers. The results of the study will fill the gap in understanding the main required engineering graduates' readiness for employability skills in the world. This study is intended to determine the most required graduates' readiness for employability skills for engineering in the HEIs in the world. Besides, it will be used to advise a policy guideline for HEIs and researchers for the understanding of graduates' readiness for employability skills requirements in the HEIs in the world.

Keywords: Employability, Graduate, Higher education, Readiness, Engineering Skills.

\section{INTRODUCTION}

The higher education (HE) has received close attention from his Majesty Sultan Qaboos in the earlier stage of the Oman renaissance. Higher education (HE) has been considered as a major factor in improving the social development and the economic growth of the Sultanate. The Omani students were sent abroad for their HE until 1986 when the Sultan Qaboos University (SQU) was established. The first academic year of 1986/1987, SQU accepted 1,127 students distributed based on gender as 678 males and 449 females. Two years later, 1989/1990, total of enrolling students were 1,550 (Al-Marjan, 2004). The HE system has expanded dramatically to include 63 higher education institutions both public and private that offer different varieties of higher educational programs. Statistically, the number of Higher Educational students has been steady with 80,000 students since 2015 (NCSI, 2015). To improve the quality of the HE, The Ministry of Higher Education (MHE) motivates this section to have academic internship and cooperation with local and international widely recognized public and private HEIs. As a result, HE has established affiliation agreements and partnerships with 18 highly ranked British HEIs (Taha, 2011).

The HE system in Oman has an essential objective aiming to enhance the skills and qualities of the graduates required by the labor market, however, this objective has yet to be met (Forstenlechner \& Rutledge, 2010). Also, other studies concluded that the skills Gap of the graduates is due to the shortfall of HEIs to provide adequate programs that link their curricula and the requirements of the industries (Al-Sulayti, 2002; Nour, 2002). Others had recommended that the HEIs need to embed the required skills into their programs curricula and create better connections and cooperation with the industries (AlMunajjed, Sabbagh, \& Insight, 2011).Due to the skills gap of Omani graduates, the number of unemployed graduates has reached 75,000 in 2016 (Oman Daily, 2016). To improve the employment of Omani graduates, the government of Oman has created important policies to enhance national employment, however, workplaces, private firms, and oil and gas industries have raised continuous concern about the quality of the HE structures. Those employers confirmed that the HE system graduates lack many important graduate readiness of employability skills (Matherly \& Hodgson, 2014). Therefore, this paper aims to conduct an extensive secondary data analysis on recent literature and related papers from years of 2015 until the present to determine the most required graduates' readiness for employability skills required to be used as a guidance for HEIs in Oman to align their programs to produce ready for employment graduates.

\section{BACKGROUND OF THE STUDY}


The Omani HEIs graduates, as many private work providers claimed, lack most of the required employability skills (Coenjaerts, Ernst, Fortuny, Rei, \& Pilgrim, 2009; Swailes, Al Said, \& Al Fahdi, 2012). The skills gap is harshly affecting the fresh graduate's employability and achievement in their workplaces (Al-Lamki, 2006; Swailes et al., 2012). Besides, graduates having adequate generic soft skills are eminently hired by industries and many employers consider highly the graduates who attained both soft and hard skills (Al-Azri, 2016).

Many types of Research conducted on citizens of Oman reveal that unemployment figures for nationals under the age of 30 are high and the private industries are reluctant to adhere to the official employment policies, fundamentally, it is because of the skills gap (Barnett, Malcolm, \& Toledo, 2015; Belwal, Priyadarshi, \& Al Fazari, 2017; Forstenlechner \& Rutledge, 2010; Silatech \& Bank, 2010). Therefore, the main principle connection between HE and the private sector is understood through the magnitude and level of graduates' readiness for employability skills that the HEIs inject into the graduates which match the employer's needs (Al-Harthi, 2011; Allen \& De Weert, 2007). This principle connection is considered as an initial factor for graduate readiness for employability which connects graduate attributes and graduates' employability skills and competencies.

\section{Concept of Graduate readiness for employability and Graduate Attributes}

The definition of Graduate readiness for employability and its concept affect the individuals and their communities in general. Employability or graduate readiness for employability has been the focus of many types of research. Some of the newly conducted studies reveal that the concept of employability still has major considerations by researchers, academia, and the industries (Finch, Hamilton, Baldwin, \& Zehner, 2013; Smith, Ferns, \& Russell, 2014; Sumanasiri, Yajid, \& Khatibi, 2015). Since the last two decades, there have been high considerations to link higher education graduates and their employment outcomes. This link was related to the graduate attributes which means the generic attributes gained by the graduates. However, 'Employability' or 'Graduate Readiness for Employability' is recently the more widely used word by governments, higher education institutions, and across industries. Though, its exact specific description has not yet been finalized (Brown \& Scase, 2005; Hillage \& Pollard, 1998; Yorke, 2006).

The definition of graduate employability or graduate readiness for employability can be understood to indicate the readiness of HEIs graduates to be employed. It signifies the graduates' possession of the required employable skills, knowledge, graduate attributes, attitudes, and workplace tasks requirements to assess them to achieve the workplace objectives (Mason, Williams, \& Cranmer, 2009). It indicates that graduates have to know the careers' requirements in their future vacation path. A new description of graduates' employability which combines the weight of generic soft skills and graduate attributes reveals the usefulness of industrial and work skills attainment (Jackson, 2016). Therefore, Graduate Readiness for Employability refers to the capability of the graduate's competence in terms of gaining the most general and specific employability skills (Stiwne \& Alves, 2010). Therefore, this definition of Graduate Readiness for Employability marks the high value of the graduates' attributes factors, and the attainment of technical industrial work skills and knowledge over theoretical excellence.

\section{METHODOLOGY OF THE STUDY}


The methodology of this paper is done by conducting extensive secondary data analysis. The related literature and papers from years of 2014 until the present are collected and then summarized to determine the graduates' readiness for employability skills required by today's employers and industries in general. The required graduates' readiness for employability skills was determined by implementing a meta-analysis technique of the literature findings.

\section{Readiness for Employability}

\section{EMPIRICAL REVIEW OF LITERATURE}

An important study conducted by Lane (2017), intended to analyse the systemic recommendations of important course of action of higher instruction level learning results and supervisor or professional entities-based competency frameworks. In this case study, intellectual abilities (information and understanding), practical abilities, communication abilities, personal and professional skills were evaluated and concluded that there are different ways in which an academic subject can relate to proficient work and contended that the valuable arrangement of such frameworks can best be accomplished through steady and continuous discussions between the performing artists so as to resolve any pointless contrasts but to empower essential differences to meet the numerous complexities of the actual world (Lane, 2017). Another interesting study about the "the myth of job readiness" focusing in written communication, employability, and the 'skills gap' in higher education, job readiness was analyzed by emphasizing in written communication skills and the writing capacities of students in perspectives including; the nature of written communication in specific working environment settings, issues concerning scholastic and proficient written communication, strategies to bargain with the writing issues of students, ways to better develop graduates for communications within the proficient work environment (Lane, 2017).

In a study conducted by Monteiro (2016), engineering graduates' perception of competencies and preparation to the labor market transition was analyzed. The aim of this study was to investigate how Building graduates from a Portuguese college assess the competencies obtained by the end of their master courses, to investigate how these Engineering graduates assess their readiness for work move, and at last, to investigate in case there's any affiliation between higher positive recognition competencies, and the planning for work transition. For that reason, a sample of 332 Portuguese senior students taking an engineering masters' degree filled surveys. The founded outcomes pointed that practical competencies, in conjunction with communication, methodological and socio-emotional competencies appear as the foremost vital indicators of labor work transition. These findings improve the significance of the integration of an effective practical component in designing educational modules as a better way to prepare graduates and to enhance their employability. The study suggested the consideration of other external components related with graduates' readiness for employability, such as the work providers conditions in future studies (Monteiro et al., 2016). In a study conducted by Gaughan, Craps, Pinxten, Saunders, and Leandro-Cruz (2017), professional roles and employability of future engineers were evaluated using a sample of 108 participants. The objectives of the study were intended to increment engineering students' understanding of the magnitude of industrial roles in engineering. Additionally, to make students reflect on their own students' character and their passion, qualities, and shortcomings. Thirdly, to investigate how to actualize these imaginative instruments within the engineering educational modules by running sample studies within the participating higher education institutes. The focus of the study was to analyze the effects of entrepreneurial skills, innovation Skills, communication and networking skills, 
teamwork and ways of thinking, and lifelong learning. The study concluded that those soft skills are essential for engineers to attain and to enhance their employability. Also, all participants of the PREFER consortium concede that engineering colleges should allow a first incentive to students' developing self-awareness, and secondly provide to students' strengthening potential for individual and proficient development (Gaughan, Craps, Pinxten, Saunders, \& Leandro-Cruz, 2017).

In a study on the influence of domicile of engineering colleges and competency profile of industrial aspirants with the aims to enlighten the gap between the expected competencies by the industries and to help the engineering colleges to understand and strengthen the competencies of the industrial aspirants. This study had number of objectives to be achieved which are: to know the Competency profile of the respondents with regard to Domicile of Engineering Colleges, to analyse the significant relationship, differences among the selected variables with Competency profile of the respondents and finally to suggest suitable measures to re-build effective Competencies among the respondents. For this study and in order to close the gap by (development of Competencies), domicile of Engineering Colleges Viz. Rural, Urban and Major city and understand the Engineering Colleges influence technical competencies and practical and behavioural skills of Industrial Aspirants were the main factors. The study was conducted with a sample size of 149 respondents using The SPSS (Statistical Package for Social Science). The study recommended that special module on development of competencies can be included in the curriculum, soft skills can be taken as one of the mode to develop Behavioural competencies, technical sessions require more duration and demo of certain mechanisms can be done, for easy understanding, Engineering colleges may enter into a Memorandum of Understanding with nearby Industry to strengthen the hands on technical competencies and final, Industrial Experts may be called for special lectures at Engineering colleges (Manoharan \& Arockiam, 2017).

In a research carried out by Ramanakumar, Ramanan, and Kumar (2016), adoption of quality management approach to achieve excellence in employability of engineering graduates of India was analysed to use the effective six sigma quality management approach embraced by the Industry in tending to their process defects, by considering higher educational institutes comparable to process workplace. This research analysed Gap in Application Knowledge of theory to Practice, Impacts and Employability by evaluating the effects of soft skill gap, analytical and Problem-solving skill gap, lack of quality knowledge, lack of domain knowledge and lack of industry interaction. This research was conducted by interviews and surveys with 713 practicing industrial professionals and 200 engineering students from 11 different institutions as respondents utilising the Six Sigma for developing a conceptual model utilises the tools hypothesis testing, Anova, regression, Correlation studies and Monte Carlo. From the research $97 \%$ of the employers' opinion stressed that the knowledge gap of applying theory to practice is a significant issue in employability of mechanical engineering graduates during the explorative study. Also, $97.4 \%$ of the respondents recognised the applied knowledge gap is the major concern for them in mechanical engineering graduate's employability. It was recommended that the research can be extended to other branches of engineering domain as there is no domain specific employability research covering the domain knowledge aspects and other factor interactions. Also, carrying research on effectiveness of employing practicing industry professionals teach the academic curriculum of theory papers that have a practical significance to percolate industry's needs. Moreover, conducting research on the effectiveness of engaging industrial professionals as experts for lecture classes includes practical importance, practical labs and also as examiners to facilitate building bridges between industry and institution and finally. 
Finally, making research on soft skills and its impacts on engineering education focus on policy decisions of government like language for medium of instructions (Ramanakumar, Ramanan \& Kumar, 2016).

In an an analysis study of school-to-work readiness by Evans et al. (2017), a number of concerns were raised regarding the readiness of students to enter the workplace. This study had investigated many issues some of which are: the readiness of school-to-work, the business required skills that are needed and necessary for success in the workforce of the 21 st Century, the current curriculum contents of such skill and what alternative methods can schools explore in order to ensure a successful school-to work transition. This study was conducted by interviews and electronics checklist. The Readiness for Employment was examined by analyzing a number of variables grouped as new skills, survival skills and soft skills. The finding of this study indicated that graduates need more applied skills such as critical thinking, the ability to collaborate, and communication skills emerged as the most important. Also, the need and importance for critical thinking, the ability to collaborate, and the necessity of communication skills for their graduates to be successful in the workplace. The checklist and interviews revealed that currently there is a "gap" between what employers need and what high schools were producing, more important, a fact of measurable results showing the emerging evolution of graduates better prepared prior to entering the workforce. Finally, this study endorsed the need to continue to make sure there is rigor and higher order thinking skills embedded in the curriculum. In addition, curriculum needs to be relevant and technology must be integrated to make sure all students were given the opportunities needed to be college and career ready (Evans et al., 2017).

In a comprehensive report on developing graduate employability through partnerships with industry and professional associations by Jollands et al. (2015), there were number of aims examined. Firstly, identifying the key issues and challenges that impact graduate employability from the perspective of a wide extend of partners over wide range of disciplines. Besides, distinguishing the gap between industry desires and graduate and academic viewpoints of graduate employability. Thirdly, building staff capacity to create educational programs and learning affordances that enhance graduate procurement of employability abilities, information and qualities. At last, distinguishing the key challenges for staff in creating educational programs for employability abilities in graduates. In this study, the graduate employability was examined using Career EDGE framework combined with stakeholders' share a professional character, employability is embedded into outlined educational modules, collaborative instructing staff utilizing student-focused instructional method and programs are outlined for the work of present and future. The study was conducted by a literature review investigating the key topics, pressures and improvements concerning student employability within Australia and expanded globally and discussions with 287 partners from a wide extend of disciplines: "engineering, ICT, life sciences, media and communications and psychology". The finding of the study pointed to that an employability system is valuable if it recognizes learning goals for reestablishment of educational programs modules for employability. Nevertheless, It must be coherent, precise, comprehensive and versatile. It ought to provide a broad understanding of employability issues and encourage improvement of sequenced educational modules. It recommended for developing a new framework that has regulated categories with scaffolded advancement. This would help staff to distinguish scaffolded learning goals appropriate for diverse academic levels. Furthermore, a high-quality educating assets are required to help staff to embrace and adjust great practice to cultivate their graduates' learning for employability, superior association and simpler access to assets is required and more prove of viable practice is required to guarantee 
practices advanced for selection are without a doubt successful. Finally, the report proposed a modern program plan is required with employability impeded consistently into educational modules and evaluation where partners share a professional character (Jollands et al., 2015).

In a study conducted by Marilyn Clarke (2018), a new approach to employability was considered by developing a framework that incorporates six key dimensions in which human capital, social capital, individual attributes, individual behaviours, perceived employability, and labour market factors. The study was based on UK and Australian data. Such study model contributed to our understanding of the individual, institutional and contextual variables that impact employability and career results among graduates. Moreover, the model also identified zones of individual obligation (for students and graduates) and zones for potential collaboration between colleges, work providers and industry sections. At last, this model advertised a multidisciplinary point of view in this manner laying the establishment for future investigations and collaborations between higher education specialists, career analysts and researchers from related areas, such as administration and psychology. The paper suggested to be expanded to incorporate labour market factor (Clarke, 2018). In a research paper on graduate attributes and employability skills conducted by Belwal et al. (2017) with a purpose to investigate the foremost prevalent graduate attributes as they apply to graduates' employability in Oman, the aims of the paper were to survey the key graduate attributes or employability aptitudes from the point of view of business in Oman in specific and the GCC nations in general, to know and acknowledge students' recognitions of the foremost common abilities that managers in Oman give esteem for admitting the entry level employments, and to analyze and contextualize graduate qualities and employability aptitudes from all-encompassing point of view, including Higher Educational Institutions (HEIs), employers, and the students. The research conducted by surveys and interviews with Omani graduates using the principles of 'hypothetic-deductive logic' and inferential analysis using a combination of focus group and survey approach.

The findings of the research paper indicated that the domain of higher educational institutes in Oman is basically confined to the essential nonspecific abilities in creating the graduate properties. Students' viewpoints on employers' determination criteria uncover that computing abilities, the capacity to work in groups, proficiency of English language, earlier training, and the graduate's identity are the five most critical employability skills in Oman. The study also concluded that at present, there's small interaction among higher educational institutions (HEIs), alumni, and industry in Oman for enhancing the employability of students. It is recommended that All the partners in Oman have to be compelled to come together to characterize employability skills judiciously by extending the domain beyond generic skills and abilities (Belwal et al., 2017). In a study conducted by Al-Mahrooqi and Denman (2018), the English language proficiency and communicative competence in Oman was studied to evaluate the implications for employability and sustainable development. This study raised a major concern about the tremendous collections of human and financial assets the government commit into supporting English language instruction, Nevertheless, this venture has clearly failed to convey the anticipated outcomes with both secondary- and tertiary-level graduates regularly characterized as being weak in the English and as having communication abilities that are insufficient for the workforce. This paper considers a number of issues related to the ways in which English language proficiency and communicative competence are created in Omani schools and colleges, with a focus on the challenges that exist inside the government education system. The suggestions of these challenges for graduate employability and feasible advancement were investigated. The study recommended methods of aligning the gap between 
students' English language abilities and the requests of the industry in Oman (Al-Mahrooqi \& Denman, 2018).

Another earlier study also conducted by Al-Mahrooqi and Denman (2016) addressing an investigating into the significance that hiring Omani school and college graduates accept the English-language communication abilities have for their work environments and the challenges they confront when utilizing these abilities in a work environment. The aims of this study were to explore the importance of employed Omani school and universities graduates admit of English-language communicative abilities are for the workforce, and the challenges, in case any, do these graduates confront when utilizing English-language communicative abilities upon entering the workforce. The study was conducted involving the organization of a 4-part survey to 321 respondents who had graduated from Omani schools and colleges and who were utilized in organizations around the nation. The findings of this study put a great emphasis to the capacity of the education bodies to deliver graduates with the abilities that the private and public segments require. Maybe one of the foremost vital of these abilities, as examined, is the capacity to communicate effectively in English - a supposition backed by discoveries detailed here. The study recommended that it is critical for directors and academic staff to concentrate on adjusting instructing more closely with the English language communication needs of the local work providers. It is additionally fundamental that genuine endeavors are made over the entire education system to supersede conventional teacher-centered strategies with student-centered, communication focused approaches (Al-Mahrooqi \& Denman, 2016).

In a PhD thesis conducted by Al Azri (2016) regarding "Academics', students', employers', and graduates' perceptions towards business management and administration undergraduate employability: implications for higher education and industry in Oman", he analyzed the undergraduate employability of Omani students undertaking BMA program. He examined the roles and responsibilities of different parties to produce graduates ready for employment including; HEIs, the quality of BMA programs and BMA workplaces in promoting BMA graduates' readiness for employability; graduates' anticipations; adequate of technical abilities and quality of learning intelligence presented by BMA programs in comparison with those required by work providers; the effectiveness of implementing certain additional-curricular and other related academically suitable activities within HEIs; and also the success of the intra HE-industrial connection in flourishing quality BMA graduates' who are ready for employment. Al Azri, by using the "Human Capital Theory", he aimed to examine the effect of HE academic BMA programs and work placement on graduates' employability. This study involved collection of data using surveys and interviews from a broad range of respondents including; "academics, students, graduates, and employers" implementing both quantitative and qualitative techniques. His thesis study concluded that collaboration between HEIs and workplaces was considered as extremely important factor for enhancing BMA graduates' employability. Moreover, having continuously live commitment among the public sector, HE management, HEIs, and industry in realizing graduates' technical required abilities was extremely recommended. In addition, results identified the strong influence of both soft and technical abilities to assist graduates readiness for employability (Al-Azri, 2016).

\section{The effect of Graduates' attributes on the Graduates' Readiness for Employability}

Graduates' readiness for employability is the main driver for HEIs all over the world. To achieve this objective, the HEIs have added a range of employable readiness required competencies including soft, and generic technical skills-based learning outcomes that are integrated into their 
degree curricula programmes hoping to improve their graduate readiness for employability. Moreover, many HEIs including Oman universities and colleges have also added internships and work placements modules aiming to enhance graduate readiness for employability. However, the feedback coming from work providers still have some concern about the readiness for employability of the newly recruited graduates. To understand the lack of the HEIs graduate's attainment of employability skills, we will need to consider other critical factors which influence graduate readiness for employability. Since the last two decades of the $20^{\text {th }}$, governments and employer's groups have put high pressure at HEIs to provide evidence of the effectiveness of their higher educational programmes in providing ready to work graduates. From academic prospective, there is a concern about the effectiveness of HEIs used strategies in developing transferable employability skills into their students (Holmes, 2013) analysed the ways universities deliver graduate employability required skills and their methods of impeded them into their programme curricula. He also analysed three influencing factors which affects graduate employability. Those factors are the human capital factors, the social capital factors and the individual behaviour factors. He proposed an employability frame work consisting of the above factors as main independent variables and contains for the human capitals; skills, competencies and work experience, for social capital; network, social class and university ranking and for the individual behaviour; career self-management and career building skills as shown in figure 1 .

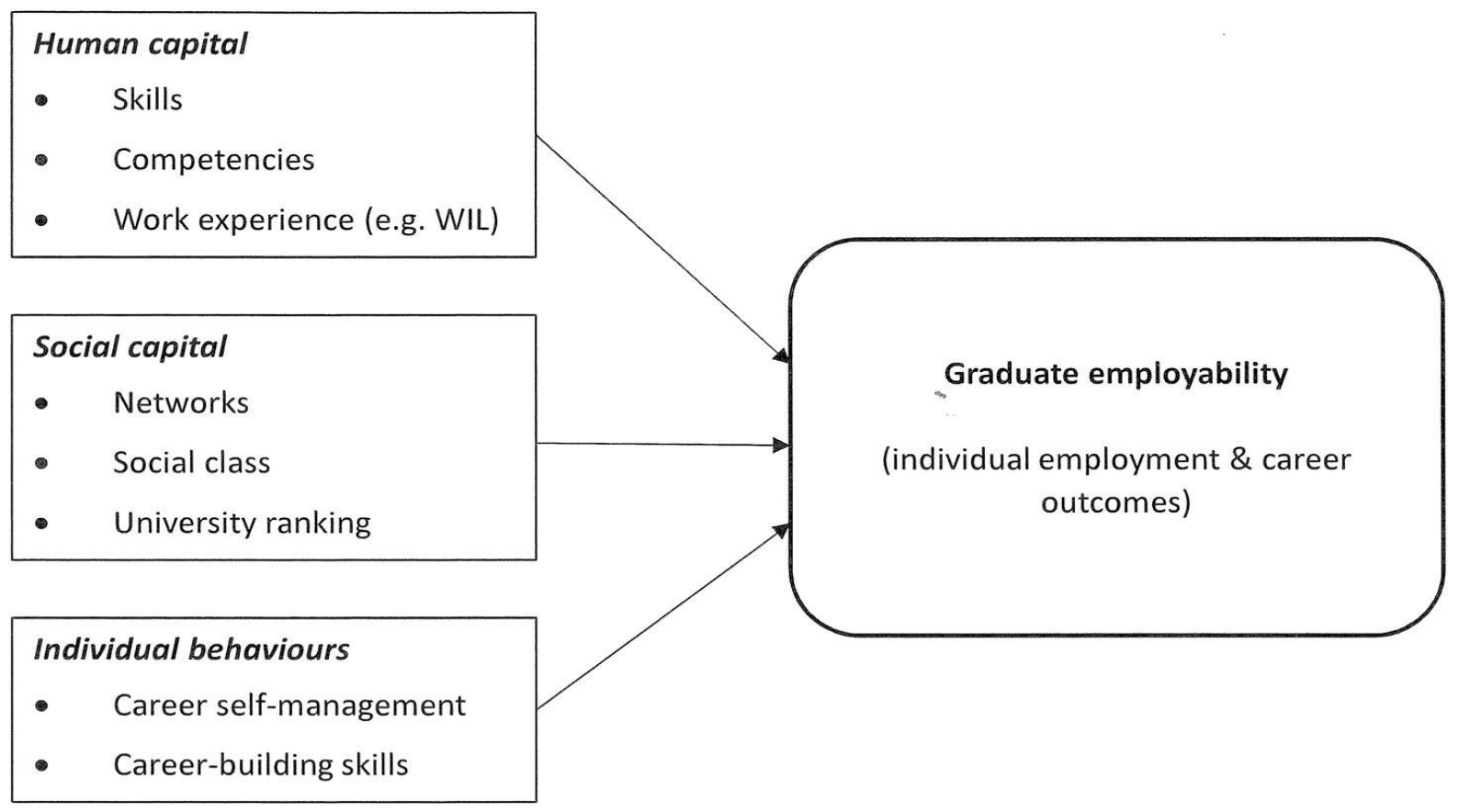

Figure 1. Graduate employability - a higher education model (Holmes, 2013).

Others Vanhercke, De Cuyper, Peeters, and De Witte (2014), emphasis essentially at selfperception for graduates employment success. They have different definition for employability to be based in the individual's perception of the possibility of getting and sustaining employment. Their perception is depicted by the employability framework illustrated in figure 2. Thus, individual perception of employability is connected to what the graduate himself do to attain competencies including his abilities, capacities and skills along with his behavioural attitude towards employment and future career. 


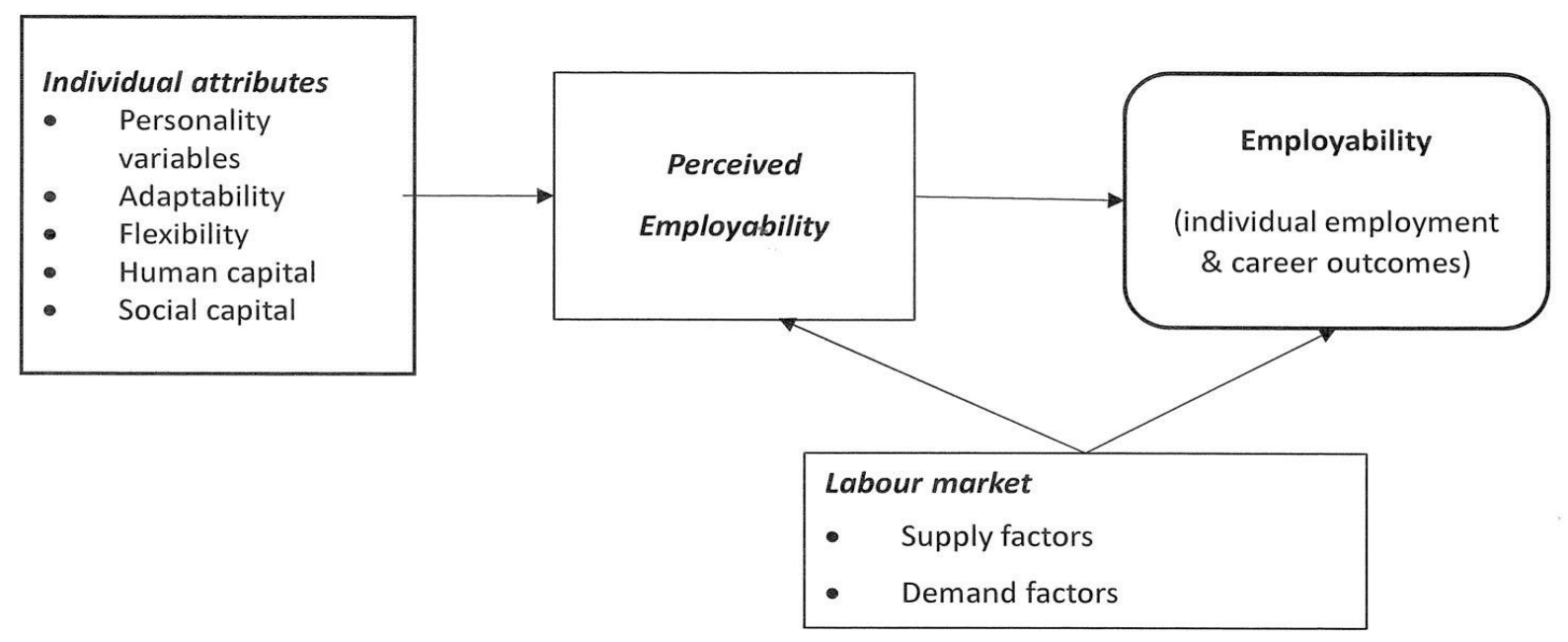

Figure 2. Determinants of individual employability (Vanhercke et al., 2014).

In his paper, Clarke (2018) combined both frameworks; the higher educational literature framework and the determinants of individual employability framework and combined them in one framework. In this new integrated framework, he added another variable to include an employability gap called as the labour market variable which is consisting of both the demand of workers and the supply of available workers in the labour market. This new model of graduate readiness for employability combines what he believed as the influencing factors for graduate employability which consisted of human capital, social capital, and individual behaviours and their attributes towards employability taking into account the labour market contribution which in total influence the graduate readiness for employment as shown in Figure 3.

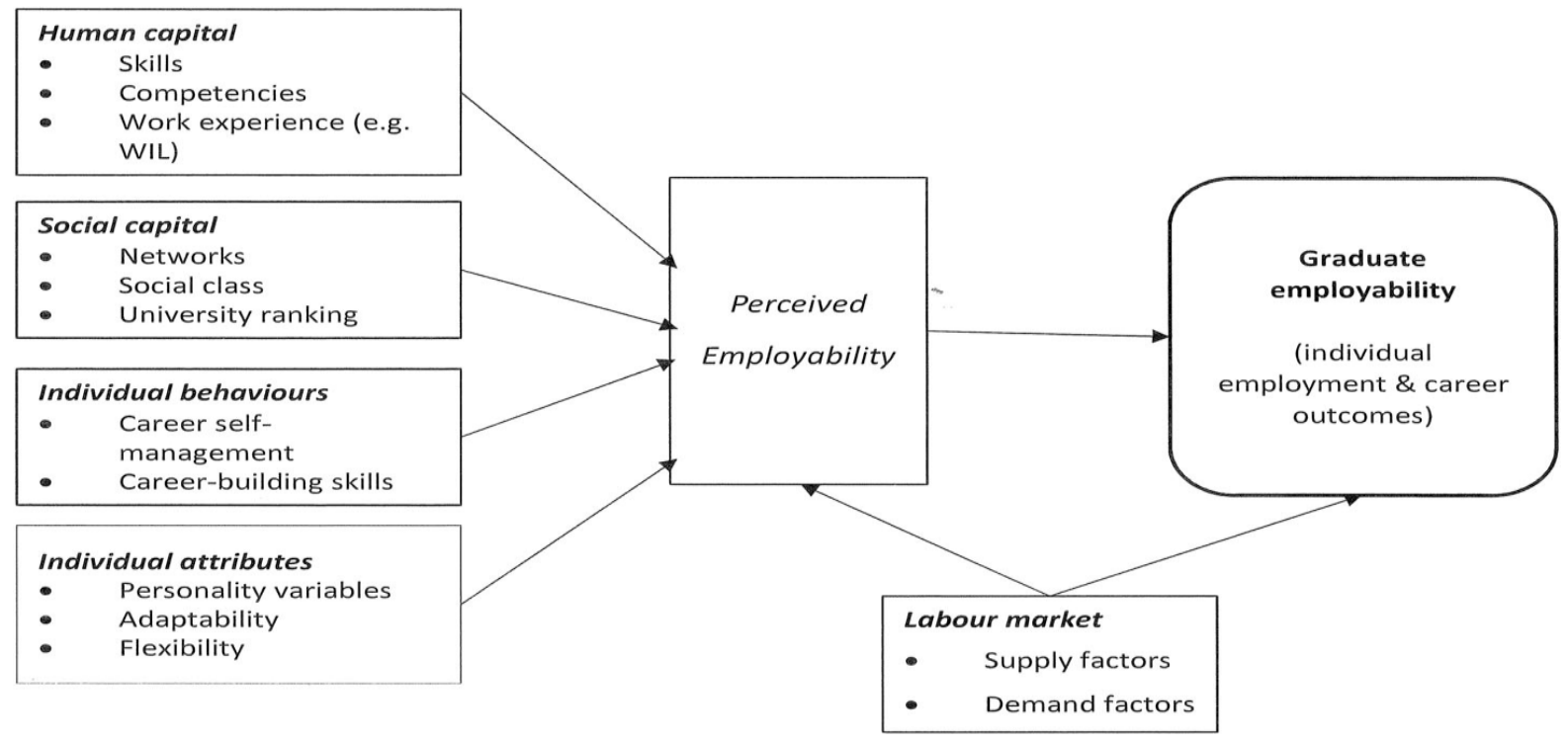

Figure 3. An integrated model of graduate employability (Clarke, 2018).

Other factors also influence graduate readiness for employability. As Chan, Fong, Luk, and Ho (2017), stated that they are a number of factors influence job attainment which are 
considered to be institution-related factors such as course quality and graduate identity. Also, Finch et al., (2013) in their study of factors affecting undergraduate employability, stressed in many factors some of them are related to human capital factors others are institutional related such as the academic reputation, pre-graduate experience and job specific functional skills. Another important factor is the utilisation of active lab environment for delivering technical industrial related skills. Hassan and Puteh (2017) analysed the importance of active learning in teaching practical competencies to enhance the quality of engineering graduates for their readiness of employability. They stated the importance of online learning, blended learning, collaborative learning, laboratory learning and interactive learning. For our research we can add other specific active but smart variables such as computer programs, Computer Based Training (CBTs), Virtual Learning Environment (VLE) and simulators. To enhance the importance of the use and the implementation of smart active labs to equip Engineering graduates with employability competencies. Also, Shetty and Xu (2018) analysed the strategies of addressing the idea of "Design Thinking" in the curriculum of Engineering programmes of HEIs . They recommended the utilisation of virtual reality environment technologies to fulfil the requirement of actual needs and visualize close to reality design solutions of new ideas and technologies. Also they suggested the use of basic design tools such as essential thinking, creative problem solving and emulation and simulation concepts.

\section{The gender and career and moral mindset effect on the graduates on graduate's readiness for employability}

So far, many factors have been analysed and identified which are widely believed to have great impacts and influence in the graduate readiness for employability. Those factors are human capitals, social capital, individual attributes, institutional and the implementation of Smart Active Labs and Environment. However, those factors are the main elements and for each factor there exist a number of antecedents which contribute in total to the design and the examination of the influence of each factor in attaining required skills for graduate readiness for employability. Moreover, many researchers believed that other factor such as Gender, Career mind-set and Moral mindset have direct influence in the implementation and attainment of graduate readiness for employability skills at the HEIs. Considering Omani working women, in recent decades they have contributed effectively to the workforce activities. As a result, the gender gap in work force participation has reduced. According to Mansour (2018), policy makers has made positive contribution to reduce the gender gap, especially in Oman and other GCC countries. This wide gender gap has resulted because of the nature of cultural ethics and believes in the region. To reduce the gender gap in Oman, in 1997, government of Oman gave a proposal to the United Nations at the Arab meeting for planning event. One of the objectives of this proposal was to promote women's independence and increase their participation in the workforce (UN Women Watch 1997). This objective intended to ensure gender equality and social justice, which was later enhanced by a Royal Decree on labour law in 2003(Mansour, 2018).

Similar to Oman, Suleman (2018) conducted a study about the employability skills of Malaysian university students. He concluded that attaining employability skills differ among students depends in the gender of the student. He analysed 12 required employability skills, he found that there was a considerable relationship between attaining required skills and genders. He listed the top 4 skills as organization skills, problem-solving, teamwork, and good time management (Suleman, 2018). Moreover, one paper stated that there is a significant gender gap in the field of technology, engineering and physics studies in spite of the efforts of HEIs to 
overcome it in the latest era. Its findings recommended the industries to employ variety of workforce including more women. This approach will make a gender balance which is vital to encourage women to enrol themselves in engineering majors and therefore attain the employable skills required by industries for the future (Strachan, Peixoto, Emembolu, \& Restivo, 2018). In a study conducted by Turen (2015), titled as "Gender Identity in Career Decisions: Masculinity and Femininity in STEM and non-STEM fields". He analysed whether gender affects females' career choices in STEM and non-STEM areas. With a sample of one hundred eighty-two female employees. He found women who have greater masculinity characteristics are more represented in STEM career type's jobs. He concluded that gender may affect female employees' career choices (Turen, 2015).

Another thesis submitted by Strachan, Emembolu, Peixoto, and Restivo (2018), titled as "A Quantitative Examination of Gender Bias and Language Paradigm in the Evaluation of Source Code". He examined gender bias in STEM aiming to explore whether or not the development of software source code built up by male or female engineers has different evaluation. In addition, he also wanted to examine if there is a close relation between the gender of the developer and the programing paradigm. His study conducted based on Social Cognitive Career Theory. The reason for using the Social Cognitive Career Theory is because is because it "encompasses perspectives of career choice, occupational roles, and gender bias, and their impact on self-efficacy". He focused on software developers and other HE students in the United States. He used an online survey. The findings of the study revealed that there were nil interaction effect, however there were clear effects in the relationship between the gender of code author and its quality, and to code paradigm and its readability. He recommended that there is a requirement to study and search on the complexities of gender related to software engineering. (Rangel, 2018). In a recent study conducted by Rebecca Strachan in 2018 titled as "Women in Engineering: Addressing the Gender Gap, Exploring Trust and our Unconscious Bias". The aim of this study is to examine ways to understand the gender gap by exploring people conception of trust and unconscious bias. The study focuses on the views of four females during long periods of their career and experiences as females in the engineering industry (Strachan, Emembolu, Peixoto, \& Restivo, 2018).

The study recommended that certain steps should be consider to reduce the gender gap in Engineering related disciplines including awareness of bias against females. In addition, providing adequate and welcoming educational workplace that value females Engineers. Finally, the study insisted that Gender gap can be eventually changed over time. For example, even though females are minorities at engineering disciplines, some of them can be raw models as STEM ambassadors for other females to enter this discipline. Different empirical studies reveals that there is an enormous gender disproportion remains in the field of technology, engineering and other sciences in many regions of the world. In the United States (US), statistics reveals that there is important difference in gender across the engineering (8\%) and technology (26\%) sectors compared to the health and life sciences (43\%) (Statistics, 2012). Other statistics concerning the situation in higher education is showing a similar picture where females students counts for 58\% in Biological and Biomedical Sciences and (18\%) in Engineering and technology (Snyder, de Brey, \& Dillow, 2016). Similar cases also stands in different European and other world countries. For instance, in 2016, the female workforce in Australia comprised less than $13 \%$ as engineers (Lewis \& McKenzie, 2017). In Japan, females makes up only 2\% of all engineers (Balakrishnan \& Low, 2016), and in Canada, 13.7\% (Emembolu, Peixoto, \& Restivo). Other world countries such as India, females accounts for $32 \%$ in engineering and technology 
(G. Joshi \& Bhattacharya, 2018). In the European Union, only 32\% percentage of females are majoring in high technology manufacturing (LESINSKIS). In the United Kingdom, females accounts only for $18 \%$ of engineering, technology and computer science undergraduates in 20152016 (National Academies of Sciences \& Medicine, 2016) and less than 10\% of professional engineers in 2016 with small rise to $11 \%$ in 2017 (Peers, 2018).

Another recent thesis conducted by Taliaferro (2018) titled as "Influencing Gender Specific Perceptions of the Factors Affecting Women's Career Advancement Opportunities in the United States". This thesis intended to study the effect of the sociological, psychological, and physiological factors that influence the career development of female workers in the United States and also analyse the effect of awareness and knowledge influenced gender specific perceptions about the factors affecting women's workplace opportunities. This study carried out by using both qualitative and quantitative methods. According to the author, this study was conducted because gender inequalities is still extremely in the U.S. workplace in 2018. Statistics show that women are paid $21 \%$ less than their males counter parts doing the same work and having similar abilities and experience. The researcher concluded "the overall statistical results demonstrate a strong impact on men's and women's perceptions and a largely reduced gender perception gap following the \#MeToo media events". Finally, the researcher recommends that more future research should be conducted regarding awareness, education, and accountability initiatives. Such studies would be more adequate to address gender effects and gaps in the workplace (Taliaferro, 2018).

To explore the gender effect in employability, Taliaferro (2018) conducted a study titled as "A Study on Corporate Perceptions on Employability skills of Engineering Graduates in information Technology Industry based on Gender". The aim of this study was to examine if employability skills based on gender candidates affect the hiring process. Therefore, this study aims to analyse any major difference in the employability skills of male and female students that causes lower percentage employment of female engineers. This study found that there were no significant differences regarding skills among males and females graduates which could significantly influence the hiring process in workplaces. As a result, this study concluded that gender employability skills was not the main reason for the lower employment ratio of female engineers in IT organisations (Taliaferro, 2018b).

Another aspect many researchers are directing the HEIs to implement is directing the students for self-employment. Such making their graduates ready for employment by starting their own business. This important competency is related mainly to the moral mindset and career mindset of the students. In a study conducted by (Brewer, 2018), he emphasised the importance of HEIs to prepare its students to attain an important employability skill which is making the students to Think like entrepreneurs. This career mind set will open the mind of the graduates into a career path as self-employed rather than waiting to be employed by an industry. Therefore, career mindset has an important influence in the graduates in their quest for possessing readiness for employability skills. It changes the way graduates see their current abilities and encourage them to expand their skills and ultimately making them experiment more ideas, and exploring better work opportunities. Mohd Zaidi Abd Rozan and Masoumeh Zibarzani (2018) conducted a "study of Entrepreneurial Mindset through the Dual Sided Role as Service Seeker and Service Provider among University Students". The study was concentrated to answer if graduates have a suitable career entrepreneurial mindset to follow entrepreneurship? Their study was based on qualitative method and sample population were the undergraduate students of Universiti Teknologi Malaysia (UTM). The findings of the study highlighted the career mindset of students. 
Unfortunately, most students were found to lack future career mindset as entrepreneurs. However, minorities had ideas to start their own businesses (Rozan \& Zibarzani, 2018).

\section{RESULTS AND FINDINGS}

This Study covers many aspects of the study literature review of the required and intended elements of the study explored literature gap. It covered Conceptual insight of employability and graduates' readiness for employability, skills required for engineering graduates' readiness for employability, the importance of proficiency of both written and spoken English language for the workplace, the graduates attributes factors the effect the acquisition of the graduates' readiness for employability skills, and finally the influencing factors of gender, career and moral mindset of engineering graduates in the attainment of graduates' readiness for employability. It has examined the Conceptual insight of "employability" and graduates' readiness for employability. "Employability" is delineated as the "ability of a graduate to be employed as a result of the skills and attitudes he attained, and the way he promotes himself to potential employers". while graduates' readiness for employability is known as the readiness of a graduate student through the attainment of most required skills, career ethics, an individual's attributes, and behaviors which aid the graduates to conduct tasks of the workplace efficiently.

The study also explored the most skills required by work providers. Researchers including (Coenjaerts et al., 2009; V. Joshi \& Ghosal, 2009; Randeree, 2009; Swailes et al., 2012) claim that the spread of unemployment among graduates is because of their skills Gap. They concluded that the HEIs are failing to provide the industries with skilled graduates. As a result of this shortfall of the HE system to produce highly qualified graduates, the work providers continued to recruit highly skilled workers internationally. "The World Economic Forum on the Global Competitiveness (2014-2015)", has emphasized the fact that the second most obstacle to investment in Oman is unskilled graduates. Many recent empirical pieces of research have classified the most required Graduate Readiness for Employability skills that are aiming to eliminate the skills Gap of HE system graduates, as; Firstly soft skills consisting of Critical thinking and problem-solving skills, communication skills, lifelong learning, and information literacy, Team-working skills, Professional ethics and morality, Entrepreneurship skills, and Leadership skills (Adnan, Daud, Alias, \& Razali, 2017; Al-Azri, 2016; Anastasiu et al., 2017; Belwal et al., 2017; Craps et al., 2017; Evans, Davis, \& Wheeler, 2017; Finch, Hamilton, Baldwin, \& Zehner, 2013; Gupta, Singh, \& Kaushik, 2018; Lane, 2017; Moore \& Morton, 2017; Neisler, Clayton, Al-Barwani, Al Kharusi, \& Al-Sulaimani, 2016)

The Study also agreed proficiency of English is considered as one of the most required employability skills in Oman that must be attained by graduates in order to be attracted by the private sector employers. Despite the huge public investment towards improving Omanis students' English language skills, graduates are still suffering from their weak proficiency in English and it is considered as an obstacle to their employability (A. Al-Issa, 2011; A. S. Al-Issa, 2014; Alrawas, 2014). Similarly, in an earlier study by (Al-Lamki, 1998), 72\% of student respondents considered the lack of written and oral proficiency of English language skills as a major obstacle that prevents them from getting employment in the private sector. Additionally, many other kinds of research specifically indicated that one of the most important graduate's employability skills for Omani graduates is the ability to communicate effectively in English (Al-Lamki, 1998, 2006; Al-Mahrooqi, 2012; Al-Mahrooqi \& Denman, 2016; Allen \& De Weert, 2007; Arkoudis, Baik, Bexley, \& Doughney, 2014; Manoharan \& Arockiam, 2017). 
There is a practical hard skill related to academic programs and Engineering specializations are also considered highly by the private sector employers. According to (Anastasiu et al., 2017). The importance of technical skills is also supported by (Holmes, Sheehan, Birks, \& Smithson, 2018) and (Cooper, Gallagher, Collins, \& Shahir, 2015). The stress to the importance of technical skills for Omani graduates were the core aspects of (Belwal et al., 2017) and (Al-Azri, 2016). The literature reviews also focused on the graduates' attributes which influence the attainment of graduates' readiness for employability skills. It was intended to identify such attributes for later provide enough evidence to build the intended study explored literature gap. Graduate readiness for employability is the main driver for HEIs all over the world. To achieve this objective, the HEIs have added a range of employable readiness required competencies including soft, and generic technical skills-based learning outcomes that are integrated into their degree curricula programs hoping to improve their graduate readiness for employability. Moreover, many HEIs including Oman universities and colleges have also added internships and work placements

\section{CONCLUSION AND RECOMMENDATIONS}

Graduate employment is considered an important success factor for higher education institutions. However, the perception of graduates' readiness for employability has a slight sophistication, meaning graduate jobs. Graduates' readiness for employability is directly related to the achievement by graduates of the required deployable skills and abilities required by stakeholders, in particular, the private sector, which calls for the acquisition of graduate skills and employable skills to ensure sustainable and productive maintain employment. Therefore, coordination between private industries and higher education institutions is essential to determine graduates' readiness for employability and identify the most required skills to produce graduates who add and endorse more values and productivity. This paper, by adapting a rigorous systematic research evaluation and performing a meta-analysis technique, has classified the key willingness required for employability grades identified by researchers. The findings can be used by graduates to increase their readiness for employability. Also, HEIs and other prospective academics and policymakers who use readiness for employability can use to improve academic curricula, promote employability requirements, and appropriate policies to produce graduates for work. Therefore, higher education system programs should be designed to provide the required knowledge, skills, and capabilities of the graduates' future employers. Higher education institutions should include the most readiness of graduates for employability skills in their curriculum. This is an essential issue to enable students to acquire the required skills that are important to their readiness for employability. From where HEIs adopt this required readiness for employability skills and also offer internships, recent graduates will be ready for work.

\section{REFERENCES}

Adnan, Y. M., Daud, M. N., Alias, A., \& Razali, M. N. (2017). Importance of soft skills for graduates in real estate programs in Malaysia. Journal of Surveying, Construction, and Property, 3(2).

Al-Azri, A. K. H. (2016). Academics', students', employers', and graduates' perceptions towards business management and administration undergraduate employability: implications for higher education and industry in Oman. Brunel University London,

Al-Harthi, H. K. (2011). University student perceptions of the relationship between university education and the labor market in Egypt and Oman. Prospects, 41(4), 535-551. 
Al-Lamki, S. M. (2006). The development of private higher education in the Sultanate of Oman: Perception and analysis. International Journal of Private Education, 1(1), 54-77.

Al-Mahrooqi, R., \& Denman, C. (2018). English language proficiency and communicative competence in Oman: Implications for employability and sustainable development. In English Education in Oman (pp. 181-193): Springer.

Al-Mahrooqi, R., \& Denman, C. J. (2016). Omani graduates' English-language communication skills in the workforce: Employees' perspectives. International Journal of Applied Linguistics and English Literature, 5(4), 172-182.

Al-Marjan, H. (2004). Educational challenges in Oman and Omanisation. Oman Observer.

Al-Sulayti, H. A. (2002). Education and human development in GCC countries: an analytical study: The ECSSR.

Allen, J., \& De Weert, E. (2007). What do educational mismatches tell us about skill mismatches? A cross-country analysis. European Journal of Education, 42(1), 59-73.

AlMunajjed, M., Sabbagh, K., \& Insight, I. C. (2011). Youth in GCC countries: meeting the challenge. Booz \& Company Inc.

Anastasiu, L., Anastasiu, A., Dumitran, M., Crizboi, C., Holmaghi, A., \& Roman, M. (2017). How to Align the University Curricula with the Market Demands by Developing Employability Skills in the Civil Engineering Sector. Education Sciences, 7(3), 74.

Barnett, A. H., Malcolm, M., \& Toledo, H. (2015). Shooting the goose that lays the golden egg: the case of UAE employment policy. Journal of Economic Studies, 42(2), 285-302.

Becker, G. S. (1962). Investment in human capital: A theoretical analysis. Journal of political economy, 70(5, Part 2), 9-49.

Becker, G. S. (2009). Human capital: A theoretical and empirical analysis, with special reference to education: University of Chicago Press.

Belwal, R., Priyadarshi, P., \& Al Fazari, M. H. (2017). Graduate attributes and employability skills: Graduates' perspectives on employers' expectations in Oman. International Journal of Educational Management, 31(6), 814-827.

Bouchard, P. (1998). Training and work: Some myths about human capital. Learning for life: Canadian Readings in Adult Education. Toronto, On: Thompson Educational Publishers.

Brown, P., \& Scase, R. (2005). Higher education and corporate realities: Class, culture, and the decline of graduate careers: Routledge.

Coenjaerts, C., Ernst, C., Fortuny, M., Rei, D., \& Pilgrim, I. M. (2009). Youth employment. Promoting Pro-Poor Growth, 119.

Evans, S. G., Davis, J., \& Wheeler, M. (2017). An Analysis of School-to-Work Readiness. Saint Louis University,

Finch, D. J., Hamilton, L. K., Baldwin, R., \& Zehner, M. (2013). An exploratory study of factors affecting undergraduate employability. Education+ Training, 55(7), 681-704.

Forstenlechner, I., \& Rutledge, E. (2010). Unemployment in the Gulf: time to update the "social contract". Middle East Policy, 17(2), 38-51.

Gaughan, K., Craps, S., Pinxten, M., Saunders, G., \& Leandro-Cruz, M. (2017). Professional Roles and Employability of Future Engineers.

Gupta, T., Singh, A., \& Kaushik, A. (2018). Placement Predict: A Review of Engineering Graduate Placement Statistics in India. International Journal of Engineering Science, 16381.

Hillage, J., \& Pollard, E. (1998). Employability: developing a framework for policy analysis. 
Holmes, D. W., Sheehan, M., Birks, M., \& Smithson, J. (2018). Development of a competency mapping tool for undergraduate professional degree programs, using mechanical engineering as a case study. European Journal of Engineering Education, 43(1), 126143.

Husain, M., Kumar, C. S., \& Saritha, G. (2017). Role of the Teacher of English: Enhancing Employability Skills to Engineering Students. Competency, 4(12).

Jackson, D. (2014). Factors influencing job attainment in recent Bachelor graduates: evidence from Australia. Higher Education, 68(1), 135-153.

Jackson, D. (2016). Skill mastery and the formation of graduate identity in Bachelor graduates: evidence from Australia. Studies in Higher Education, 41(7), 1313-1332.

Lane, A. (2017). The systemic implications of constructive alignment of higher education level learning outcomes and employer or professional body based competency frameworks.

Leslie, L. L., \& Brinkman, P. T. (1988). The Economic Value of Higher Education. American Council on Education/Macmillan Series on Higher Education: ERIC.

Mason, G., Williams, G., \& Cranmer, S. (2009). Employability skills initiatives in higher education: what effects do they have on graduate labor market outcomes? Education Economics, 17(1), 1-30.

Matherly, L. L., \& Hodgson, S. (2014). Implementing Employment Quotas to Develop Human Resource Capital: A Comparison of Oman and the UAE. International Journal of Liberal Arts and Social Science, 2(7), 75-90.

McMahon, W. W. (2009). Higher learning, greater good: The private and social benefits of higher education: JHU Press.

Mincer, J. (1962). On-the-job training: Costs, returns, and some implications. Journal of Political Economy, 70(5, Part 2), 50-79.

Monteiro, S. C., Almeida, L. S., \& Vasconcelos, R. (2016). Engineering graduates' perception of competencies and preparation for the labor market transition. ICERI Proceedings, 2016, 3785-3790.

NCSI. (2015). Statistical Year Book. In: NCSI Muscat, Oman.

Nour, S. (2002). Skill creation, human resources development, and policy intervention: a survey and interviews with policymakers and experts in the UAE. February-April, unpublished document.

Oluwatobi, A., Ayedun, C., Ajibola, O., Iroham, C., \& Akinjare, O. (2017). Employers Perspective of The Employability Skills-Gap in Real Estate Education In Nigeria.

Rahim, H. L., \& Lajin, N. F. M. (2015). Social entrepreneurship and graduate employability. International Academic Research Journal of Social Science, 1(1), 33-40.

Schultz, T. (1963). The Economics Value of Education. New York and London. Columbia. In: University Press.

Silatech, G., \& Bank, W. (2010). The Silatech Index: Voices of Young Arabs. In: Gallup Center for Muslim Studies, Silatech Washington, DC.

Slaughter, S., Taylor, B. J., \& Rosinger, K. O. (2015). A critical reframing of human capital theory in US higher education. Critical approaches to the study of higher education: A practical introduction, 80-102.

Smith, C., Ferns, S., \& Russell, L. (2014). Conceptualizing and measuring'employablity-lessons from a National OLT Project. Paper presented at the http://acen. edu. au/2014conference-proceedings/. 
Stiwne, E. E., \& Alves, M. G. (2010). Higher education and employability of graduates: will Bologna make a difference? European Educational Research Journal, 9(1), 32-44.

Sumanasiri, E. G. T., Yajid, M. S. A., \& Khatibi, A. (2015). Conceptualizing Learning and Employability" Learning and Employability Framework". Journal of Education and Learning, 4(2), 53-63.

Swailes, S., Al Said, L., \& Al Fahdi, S. (2012). Localization policy in Oman: a psychological contracting interpretation. International journal of public sector management, 25(5), $357-372$.

Taha, H. A. (2011). Operations research: an introduction (Vol. 790): Pearson/Prentice Hall.

Yorke, M. (2006). Employability in higher education: what it is what it is not (Vol. 1): Higher Education Academy York.

\section{Copyrights}

Copyright for this article is retained by the author(s), with first publication rights granted to the journal. This is an open-access article distributed under the terms and conditions of the Creative Commons Attribution license (http://creativecommons.org/licenses/by/4.0/) 